\title{
Gender Inequality in Pakistan Caused by Domestic Factors and Conflict Resolving Based on CEDAW
}

\author{
Dewi Masitoh ${ }^{1}$, Firdha Ayu Pramesti ${ }^{2}$ \\ ${ }^{1}$ Department of Political Science, Faculty of Social and Political Science, Diponegoro University, \\ Central Java - Indonesia \\ ${ }^{2}$ Department of Political Science, Faculty of Social and Political Science, Diponegoro University, \\ Central Java - Indonesia \\ Email: dewimasitohlty117@gmail.com \\ Submitted: 20 July 2020 | Accepted: 28 December 2020
}

\begin{abstract}
Gender inequality in Pakistan has been going for a long time from year to year. This can be evidenced by the results of a report from The Global Gender Gap Index in 2018 that was released by the World Economic Forum (WEF), Pakistan was the second worst country in the world in terms of gender equality, especially for the treatment of women, which ranks 148th out of 149 country. The aims of research are women's participation is needed in a country by guaranteeing their freedom and welfare of state. If the lack of women's participation will be one of the roots of socio-economic and demographic problems that have been experienced by Pakistan until today. This research will use qualitative research methods, that emphasize the observation and understanding of a social phenomenon, where data is collected through secondary data and literature review. This research will use two theoretical frameworks, they are: Feminism and Human Rights. The main finding of the research was found in detail about how the problem of gender inequality in Pakistan; the reasons of gender inequality has been going on for a long time; and how about the conflict resolving from Pakistan Government based on International Law.
\end{abstract}

Keywords: Gender, Inequality, Feminism, Human Rights, Conflict.

\begin{abstract}
Abstrak
Ketidaksetaraan gender di Pakistan disebabkan oleh faktor domestik, di mana telah berlangsung lama dari tahun ke tahun. Hal tersebut dapat dibuktikan dengan hasil laporan The Global Gender Gap Index pada tahun 2018 yang dirilis oleh World Economic Forum (WEF), di mana Pakistan merupakan negara terburuk kedua di dunia dalam kesetaraan gender, khususnya tentang perlakuan terhadap wanita, yang menempati peringkat 148 dari 149 negara. Tujuan penelitian ini adalah untuk melihat bahwa partisipasi perempuan diperlukan dalam suatu negara agar dapat menjamin kebebasan dan kesejahteraan masyarakat. Kurangnya partisipasi perempuan akan menjadi salah satu akar permasalahan sosial ekonomi, budaya dan demografi yang selama ini dialami oleh Pakistan hingga saat ini. Penelitian ini menggunakan metode penelitian kualitatif, yang menekankan pada observasi dan pemahaman terhadap suatu fenomena sosial, dimana data dikumpulkan melalui data sekunder dan studi pustaka. Penelitian ini akan menggunakan dua kerangka teori, yaitu: Feminisme dan Hak Asasi Manusia. Penelitian ini akan membahas secara rinci tentang bagaimana permasalahan ketimpangan gender di Pakistan; alasan mengapa isu ketidaksetaraan gender telah berlangsung lama; dan bagaimana Pemerintah Pakistan menyelesaikan konflik dengan Hukum Internasional.
\end{abstract}

Kata kunci: Ketidaksetaraan, Gender, Feminisme, HAM, Konflik. 


\section{INTRODUCTION}

One of the countries experiencing by gender inequality or discrimination is Pakistan. This is evidenced by the results of a report from The Global Gender Gap Index in 2018 that was released by the World Economic Forum (WEF), Pakistan is the second worst country in the world in terms of gender equality, especially for the treatment of women, which ranks 148th out of 149 country (Ahmed, 2018).

By applying the concepts of feminism and human rights in this research, it is necessary to have women's participation in a country by guaranteeing the freedom of their people. Therefore, this research will discuss in detail about how the issues related to gender disparity problems and why gender inequality occurs and how Pakistan implements the principles of International law, it is based on CEDAW (The Convention on the Elimination of all Forms of Discrimination Against Women). This research will also give a presentation related to some examples of some policies and case studies of gender inequality in Pakistan.

\section{METHOD}

This research will use qualitative

research methods. Qualitative research methods are research methods that emphasize the observation and understanding of social phenomena, which is then interpreted and explained through words. The object of this research method is human, relationship with interaction and the relationship (McCusker, 2015).

According to K. McCusker and S. Gunaydin in their book by the tittle "Research Using Qualitative, Quantitative Methods or Mixtures and Choices Based on Research" explained that qualitative method is suitable for answering questions 'how' 'according to phenomena. This method is subjective and inductive and does not use statistical mechanism (McCusker, 2015).

This qualitative method is very suitable to be applied in this research, which is discussed in relation about three problems in Pakistan, they are: First, 'how' to analyze the gender inequality in Pakistan. Second, 'how' the causes of the problem about gender inequality. Third, 'how' the efforts of the Government of Pakistan in equality gender. These problems will discuss by using two concepts, they are: 'Feminism' and 'Human Rights'.

The qualitative method is a research method that is flexible and dynamic, which means that it is open to changes, both approved and 
changed during the research process (McCusker, 2015). The qualitative methods can be done by taking case studies of existing social problems. This method is also done by developing values and taking conclusions based on the processes and data that have been obtained (Direktorat, 2019).

The qualitative research methods can be done in two ways. First, exploratory by knowing in detail about the objects and problems regarding the gender inequality in Pakistan. From the explorative way in this research, the author takes two concepts in answering and analyzing the gender inequality in Pakistan. The two concepts that have been taken by the author, namely: Feminism and Human Rights. These two concepts, the author has a limitation in the discussion so that it is not too broad in writing.

Second, descriptive is the continuation process after explorative, in which this research process aims to describe the object or phenomenon that will be examined and that will be discussed in detail. From the descriptive method in this writing, the authors describe the two concepts (Feminism and Human Rights) by analyzing about the gender inequality in Pakistan which had been happening for years.
After that, the author will discuss about how the causes of the problem about gender inequality and the efforts of the Government of Pakistan in equality gender. This will be supported by some data that will show how about index gender equality ranked from 2017 until 2018.

Then, after using the two previous research methods, they are: explorative and descriptive ways, the author will provide an explanation of an object, so that a conclusion will be drawn as a result and essence of this research (Hancock, 2009).

By using this qualitative method, the author can give some explanation and explanation of some objects in detail. The results from qualitative methods can be proposed and result in the development of concepts, interpretations, suggestions, solutions or evaluations of problems that have been discussed by the authors. And at the end, the authors will take conclusions as a result and essence of this research (Hancock, 2009).

The technique of retrieving data in this research will use a method of retrieving secondary data. Secondary data is a method obtained through literature by searching the data that has been processed by observing, collecting and taking some references or sources that already exist, such as books, data, journals and articles 
through the internet. Related, in this study will be discussed in detail by conducting a review of some reliable data via the internet. Then, the data in this research also narrative, which is a sentence that discusses about the complexity of the problem (Cochran, 2007).

Some secondary data used in this research, they are: First, Index Gender Equality Ranked from 2017 to 2018. Second, Number of 'Honor Killing' in Pakistan (2004-2016). So, from these data, the author will see and found about how the situation gender inequality in Pakistan and found the causes of the problem about gender inequality which had been happening for years. So, the author also can find about how effective the efforts from the Government of Pakistan in gender equality.

\section{THEORETICAL FRAMEWORK}

\section{Feminism}

The author will use the concept of "Feminism", which is an acceptable ideology that needs to be fought for the rights of women, so they get the same rights and they do not get discriminatory treatment in a society. Feminism has developed quite rapidly along with the appears of critical flow. There are various developments in feminism in various genres especially in feminist law as liberal feminism to post modern feminism. Feminist jurisprudence or feminist legal theory from late 1960s to the 1970s discussing about the possibility of realizing laws with gender equality dimensions, because of neutrality and conceptual objectivity of law has positioned women as potential victims, and actually in many fields and in frequent circumstances discriminate against women because of the special conditions the experience, such as menstruation, pregnant, and so on. Eventhough the focus of attention various based on feminist law still place women in their proper position. Its mean that the experienced of oppression by women, feminist try to give encouragement and inspiration about the importance of women's roles and positions, especially in the cultural, and socio-economic sector. This concept is very suitable to be applied in this research because it discusses the rights of women who have been ruled out because of gender inequality or discrimination.

The concept of "Feminism" was appointed because it was supposed to protect women's rights from various conflicts that often detrimental and harm to women. This concept emphasizes more on how to position women's subjects in certain societies. The concept of "feminism" has fight for two very important things for women, they are about equality with 
men and autonomy in determining what is the best for their self (Soetjipto, 2013).

\section{Human Rights}

The author will use the concept of "Human Rights", which is a concept that believes in the rights that have been linked to human beings from birth and applies to all genders, nationalities, residences, ethnic, religion, language, skin color and all of statuses. All of these rights are interrelated and cannot be separated.

The concept of "Human Rights" has developed into an international norm that defines what is needed for humans to develop. The norm of "Human Rights" has an interrelated relationship between individual rights or collected with other entities, namely the state as the owner of the obligation.

The essence of "Human Rights" is related with the implementation Pakistan government about gender equality that is not equal in line with international law and human rights principles especially Pakistan includes a country ratifies CEDAW (The Convention on the Elimination of all Forms of Discrimination Against Women) These rights can consist of rights in various aspects, namely: political, economic, social, cultural and legal system. Therefore, a country must respect and guarantee the rights of citizens, in order to their rights can be fulfilled properly (Right, 2008).

\section{RESULT AND DISCUSSION}

\section{Disparity Problems of Gender Inequality in Pakistan}

By applying the concepts of feminism and human rights in this research, it can be seen that a country can advance if there are society participations in fulfilling the life and interests of country. One of them is by women participation in improving the political, economic and social sectors. One way is to guarantee the participation of women in a country by guaranteeing freedom. Thus, if there is a lack of women's participation, this will be one of roots of the socioeconomic, cultural and demographic problems that have been experienced by Pakistan until today (Quresh, 2019).

There is an increase from women's participation in Pakistan, from $26 \%$ to $45 \%$. This level of participation has increased doubled in 22 years, from 1992 to 2014. Although there has been an increase of women's participation in Pakistan, but it has been not changed, especially in gender equality and gender inequalities from women's employment status

When politics in a feminst perspective is always defined as power and legislation, this political meaning the leads to the birth of idea 
empowering the public role of women through political channels. Women are always directed to be able in position themselves and take part in the power elite, legislative institutions, or at least have the courage to the fight for their own aspirations independently without any influence or pressure from any party. So feminist always question the quantity of women who sit on legislative. According to the increase number of participation but the gender is still inequality because women parliamentarians continue to face numerous obstacles includes the prevalent socio cultural taboo in society and limitations economic sector by high cost of election campaigns that restricts the number of women to contest elections and dominance, that is why socio cultural and economic sector impact with the gender inequality in Pakistan (Quresh, 2019).

This is proven by the results of a report from The Global Gender Gap Index in 2018 released by the World Economic Forum (WEF), Pakistan is the second worst country in the world of gender equality, which ranks 148 out of 149 countries. Then, in 2019, Pakistan will also be in the same position as 2018, which is 148th out of 149 countries (Foundation, 2019). There are three other Muslim countries which are in the lowest rank in gender equality, namely: Egypt, Saudi Arabia and Yemen, which are in the lowest position, which is 149th. These are four countries have become the countries with the worst policies for treating women. This can be seen in the following index image below (Ahmed, 2018):

Figure 1: Index Gender Equality Ranked (2018)

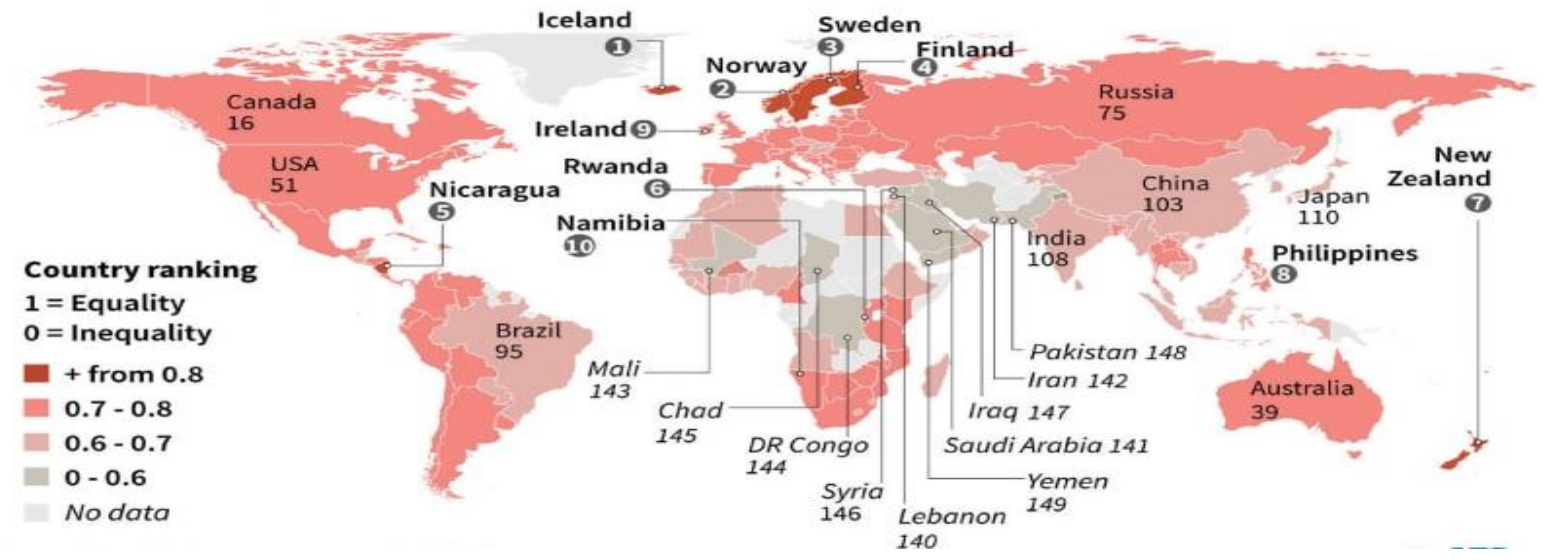

Source: Dawn (2018).

Pakistan's population has increased by $1.93 \%$ per year, but until now, Pakistan has not shown an increase their socio-economic sectors. In measuring gender equality, it can be seen from four sectors, there are: First, 
the education sector and second, the participation and economic opportunity sector. Pakistan has ranked 146th. Third, the health sector has ranked 145th and fourth, the political empowerment has ranked 97th. Egypt, Saudi Arabia, Pakistan and Yemen have the worst performance, which is less than $7 \%$ of $34 \%$ of women's managerial positions in all countries (Ahmed, 2018).
The World Economic Forum (WEF) explained that gender equality can be seen from the education, health, life sustainability sectors, economic opportunities and political empowerment from 144 countries. Pakistan has ranked the second worst, which is 143th from 144th. While, 144th place has been occupied by Yemen. This can be proven in the following index images below (Reuters, 2017):

Figure 2: Index Gender Equality Ranked (2017).

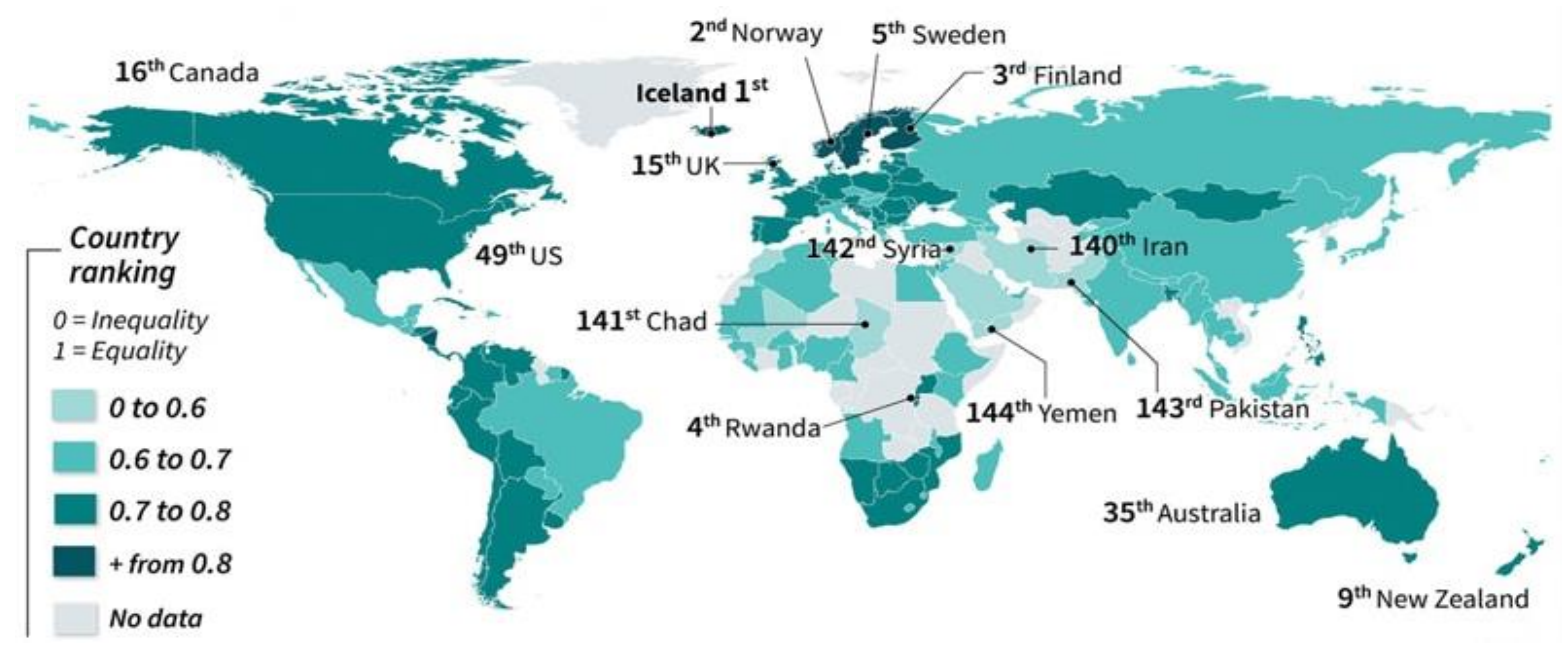

Source: Reuters, (2017).

From the picture above it has been explained that in 2017, Pakistan ranked 143 out of 144 countries. In the participation and economic opportunities, it also ranks 143th, education attainment ranks 136th, health and survival ranked 140th and the political empowerment sector ranks 95th (Talpur, 2017). Pakistan's inequality gender gap of as much as
58\% makes The World Economic Forum (WEF) speak up by saying that women in Pakistan must wait for 217 years to be able to earn an equivalent income for men. Gender equality should be a moral and economic necessity, in order to be welfare state. This was consistent with what Saudia Zahidi has stated as head of education, gender 
and work of the World Economic Forum (WEF) said (Reuters, 2017):

"Even though qualified women are coming out of the education system, many industries are failing to bire, retain and promote them, losing out on a wealth of capacity" (Reuters, 2017).

In 2016, according to The Global Gender Gap Report, Pakistan ranked 143th out of 144 countries. In participation and socio-economic opportunities it also ranks 143th, education achievement ranked 135th, health and life sustainability ranked 124th, political empowerment ranked 90th (Talpur, 2017).

In 2015, Pakistan ranked 144th out of 145 countries in the world. Pakistan got a score of 0.559 from the zero score which is the lowest score. From this index measures of equality in several aspects, they are: labor force participation, equality of wages for similar jobs, estimated income earned, number of legislators, senior officials, managers and the number of professional and technical workers. And in 2014, Pakistan ranked 141 out of 142 countries in the world (Talpur, 2017).

From all the aspects above, it can be seen that there is a gender wage gap in Pakistan and poor participation of women workforce, which is $22 \%$ compared to men, which is $67.8 \%$. Then, for similar work, women are paid $23 \%$ less than men. The average monthly income of women is Rs 9,760, compared to men's monthly income, which is Rs 15,884 . Then, women are employed as managers only by $0.3 \%$, professional workers by $6.4 \%$ and as technical workers by $0.9 \%$ (Hisam, 2016).

There is one of many case studies about the low gender equality in Pakistan in 2014. This has been experienced by a housewife named Zeema Khatoon. She has five children and works every day in the cotton fields for hours in the countryside of Sindh Province, Southeast Pakistan. Where, the distance from his house to field is around 225 Kilometers. She was willing to work, even though the wages she earned did not suitable with her energy and sweat which she had spent. She only gets a wage of USD 2 per day or around IDR 24,000 (Agustina, 2014).

A number of other women's groups said that the income in 2014 had decreased compared to last year, 2013. Where, each of them could get a wage of USD 3.5 or around Rp 46,000. This is still being done by Pakistani women because the majority of them are not educated. Thus, many of them are illiterate and not good at counting, so their bosses often tricked them by cutting their salaries. And Khatoon also realized when she had been deceived by her boss after she learned 
to count from his school children. Then, the majority of female workers who are still young, have been the target of victims from sexual harassment from their bosses (Agustina, 2014).

In 2012, the wages of women farm workers in Pakistan only earned around USD 1.46 per day, which is around IDR 16,000. In 2007, they received their wages were around USD 1.68 per day, which was around IDR 18,000 (Agustina, 2014). The economic disparity is one of the causes from increasing gender wage gap in Pakistan and causing poverty. According to the analysis of The Pakistan Labor Force Survey from 2013 to 2015, the gender wage gap in Pakistan is $26 \%$ of the entire Pakistani labor force without calculating differences in worker characteristics (Talpur, 2017).

There are about 10 times more women than men who have been involved in household, caring for children and elderly. This causes women to be poorer from time to time because they do not have job skills. Indirectly, women have spent more time to work per day, which is $41 \%$ compared to men who only amount to $12 \%$. Women's domestic work is not counted in national data. Women have done their work around 2.5 times the amount of unpaid by their boss. So, globally it is estimated this work is to be worth around $\$ 10$ trillion a year.
This means Pakistani women make their contribution to the Pakistan's economy for free. This is like the following quote (Talpur, 2017):

"Women's household work is counted nowhere in the national data. It is estimated that women carry out around 2.5 times the amount of unpaid care work that men do, and globally this work is estimated to be worth around $\$ 10$ trillion” (Talpur, 2017).

The majority of the labor force in Pakistan still works in the agriculture and animal husbandry sectors, especially for rural women, but they are not given a decent and fair salary. They also work in the industrial, mining and labor sectors manually without modern facilities. On the contrary, there are still rarely workers who need special skill and expertise, such as doctors, nurse, pharmacy, teacher, and so on. This causes make it even more difficult for Pakistan in equality gender (Reuters, 2017).

\section{Causes of the Problem about Gender Inequality in Pakistan}

Pakistan's society still believes that women belongs to a man, so this belief makes a women object of value to a man (Bhanbaro, Sadiq, Wassan, M. Rafique, Shah, Muhbat, Talpur, Ashfaq A, Aijaz Ali , 2013). By applying the concepts of feminism and human rights in this research, gender 
inequality gender in Pakistan can be caused by two factors (Pratiwi, 2012):

First, cultural factors, many people of Pakistan still believe in the strength of male chawinistic, that men are the most powerful or superior human beings compared to women. This tendency can occur and has taken root in the community because of the cultural influence or beliefs of local indigenous people and religious understanding (Pratiwi, 2012).

Second, legal factors, the process of making law which ultimately affects a country's policy. That the law resulted in discrimination against women because it's only concerned with the needs and interests of certain interest groups. (Pratiwi, 2012).

From the two factors above, about culture and law, this can be seen from the weakness of the law regarding the handling of sexual harassment and violence against women. One of the implementations from cultural factors that has taken root in Pakistan is still a belief that they called as 'The Concept of Honor Killing' which must be based on a cultural tribe. Thus, if women are married, then it is considered the property of a man (husband) and women's personal rights have been lost. (Khan, 1999).
The implementation of this 'Honorary Concept' is 'Honor Killing' which in Urdu (Pakistan) has been called 'Karo-Kari', which is honor killings. Literally, this 'Karo' means a sinful man, while 'Kari' means a tainted woman. If a woman do 'Kari', which is to have an affair with a man who is not her husband, then she can be said to be a 'Disgrace' (Jamal, 2015). The mean 'disgrace' here has been expanded and has many meanings, that the women acts do not have morals and behaviors, such as: married of her own choice, refusing to marry a prospective parent's choice (arranged marriage), women having an affair and want to divorce from their husband, dress modestly, follow the foreign cultures which is different from their ethnic groups culture, change beliefs and religions and do the deviant acts such as: being a shemale, gay and lesbian. (Mursalin, 2017).

For women who have committed one of the examples from disgrace acts as the text above, then the women is permitted to be punished directly by using our own hands by being killed by her father, husband and brothers. Meanwhile, can be punished indirectly, their family can hire the other people to kill women who have committed a disgrace act (Asruchin M. , 2012).

According to annual report, from 2004 to 2016 the number of victims due to the 'Honor Killing' incident has 
increased from year to year. This can be seen in the graph below (HRCP, 2004):

Chart 1: Number of 'Honor Killing' in Pakistan (2004-2016)

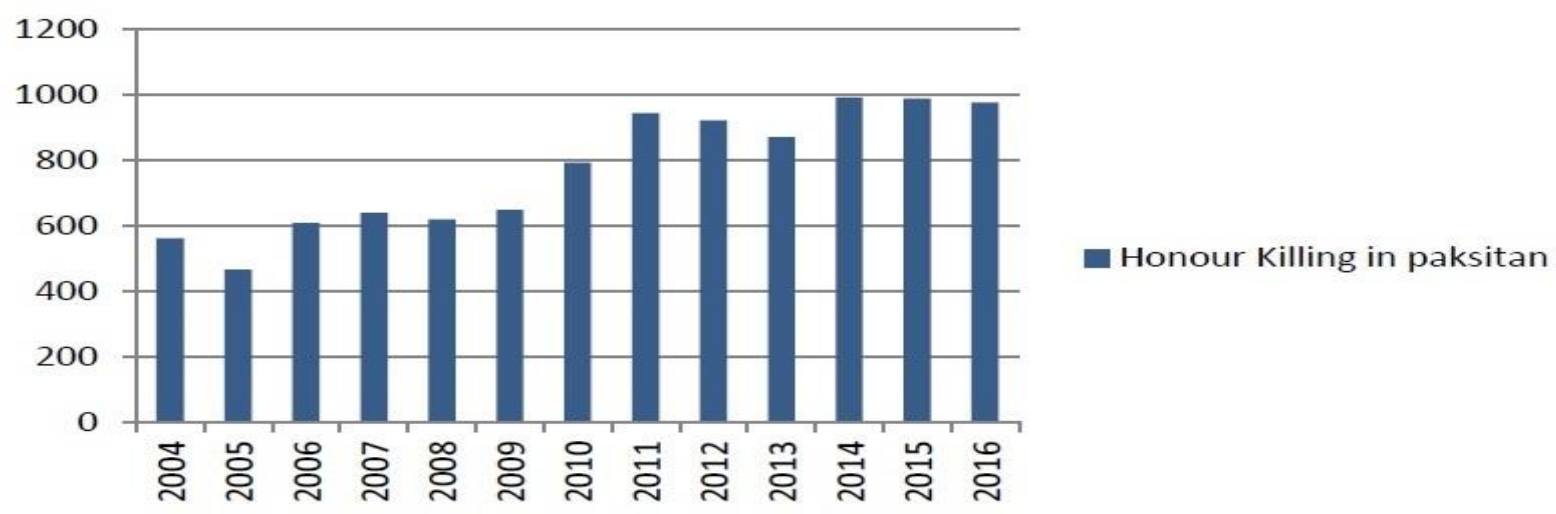

Source: HRCP (Human Rights Commission of Pakistan), (2004).

The graph above has explained that the number of victims due to the 'Honor Killing' incident in 2004 were 560 people, 2005 were 465 people, 2006 were 607 people, 2007 were 638 people, 2008 were 618 people, 2009 were 647 people, 2010 has 791 people being killed, 2011 were 943 people, 2012 were 920 people, 2013 were 869 people, 2014 were 990 people, 2015 were 987 people, 2016 were 975 people (HRCP, 2004).

Beside from cultural and legal factors, there are several other factors that can cause gender disparities in Pakistan. This is explained as follows:

First, lack of the role from Pakistan Government in prioritizing some sectors that can support Pakistan's economic progress by loosening their policies towards women. This proven by several sectors that have not been maximized in handling, such as the 'Education Sector'. Half of Pakistani women are still not getting education, where only $10 \%$ of them have received education after high school. Thus, making them do not have the opportunity to work with high salaries. The women who have higher education, will get decent and quality jobs. Then, 'Health Services' in Pakistan are still very bad. The health sector is also influential in order to equalize gender in Pakistan. Besides that, the "Political Sector" in Pakistan, has the lower representation of women (Quresh, 2019).

Second, the targets in the Millennium Development Goals (MDGs) cannot be fulfilled to reduce the maternal mortality ratio. This is 
because the Government of Pakistan has not implemented anti-early marriage law. If this law has been implemented, it will change the behavior of the community, so that women in Pakistan can get a better quality education, have a much better life and reproductive health and have better economic opportunities (Quresh, 2019).

Third, social norms that do not support women's involvement in socio-economic activities, thus requiring them to return to the informal sector, that is, sectors that do not have to have skills in their work. The Pakistan's Government should implement laws based on households and domestic workers. Thus, this can solve socio-economic problem with very low wages and lack of access to social security (Quresh, 2019).

Fourth, the gender wage gap is still very high in the world. This is proven by the position of Pakistan in the 148th position out of 149 countries. Substantially, Pakistani women do not have work that requires Science, Technology, Engineering and Mathematics (STEM) skills. This problems leads to low participation and wages of women in economic sector skills, where Pakistan only has $22 \%$ of women workforce (Ahmed, 2018) This is proven by wage inequality between men and women workers in the agricultural sector, where male workers have earned Rs 300 per day, while female workers only receive Rs 170 per day. Then, women workers also only earn less than men, which is around $32.82 \%$ of the skilled agricultural sector, while men earn around $67.18 \%$ (Talpur, 2017).

Pakistan only has $1 \%$ of women entrepreneurs, this is because Pakistani women have various problems and challenges, such as limited access in markets and finance (Quresh, 2019). If we look this problem, there is a quote that says about Pakistan will not fulfill their development targets, if it still does not care about the importance of women's participation and become a competitive country and society in the 21 st century. This has been quoted with a sentence that says about (Quresh, 2019):

"Without increasing women's
participation, Pakistan cannot meet its
development targets or reasonably
expect to become a competitive state and
society in the 21st century" (Quresh,
2019).

Therefore, Pakistan requires women's participation and contribution getting into the working world in the public and economic sectors. Besides that, a policy on gender equality is needed and there must be a transformation of social norms that can change the status of women's socio-economic participation 
in positioning their status in a country (Quresh, 2019).

\section{Conflict Resolving from Pakistan Government based on International Law: CEDAW}

Pakistan is a country that has ratified The Convention on the Elimination of all Forms of Discrimination Against Women (CEDAW), but Pakistan still does not have a sense of responsibility to eliminate the problem of discrimination against women.Pakistan as a country that ratifies The Convention on the Elimination of all Forms of Discrimination Against Women (CEDAW) in 1996. Actually, the government of Pakistan has made various various efforts in supporting the implementation. Since 1996s, NGO began to show their supervisory function by releasing statistics data regarding honor killing each month or year to raise awareness public. The government is also trying to analyze the root causes of honor killing. By forming a Commision of Inquiry for Women in 1997 which serves to provide policy recommendations in dealing with honor killing as a form of implementing The Convention on the Elimination of all Forms of Discrimination Against Women (CEDAW). However, because it only serves to analyze and proposing policies in the end of this commission did not have that effect significant in order to overcome honor killing.

One of examples and comply with the existing regulations in CEDAW by referring to chapter IV, article 15 paragraphs 1, 2, 3 and 4 , as follows (CEDAW, 1979):

\section{Article 15}

1. States Parties shall accord to women equality with men before the law.

2. States Parties shall accord to women, in civil matters, legal capacity identical to that of men and the same opportunities to exercise that capacity. In particular, they shall give women equal rights to include contracts and to administer property and shall treat them equally in all stages of procedure in courts and tribunals.

3. States Parties agree that all contracts and all other private instruments of any kind with a legal effect which is directed at restricting the legal capacity of women shall be deemed null and void.

4. States Parties shall accord to men and women the same rights with regard to the law relating to the movement of persons and the freedom to choose their residence and domicile (CEDAW, 1979):

Then, in chapter III article 25 (2) states that: 
"There shall be no discrimination on the basis of sex alone" (CEDAW, 2005).

And Article 27 states that:

"No citizen shall be discriminated against in respect of any such appointment (in the service of Pakistan) on the ground only of race, religion, caste, sex, residence, or place of birth" (CEDAW, 2005).

Even though, there are regulations in CEDAW, Pakistan has still a lot of gender discrimination problems and has not shown significant changes. This can be evident by many cases of honor killing in Pakistan, but only about 10 to $20 \%$ have been reported and received punishment. Then, there are still many women in Pakistan who still do not feel any protection from the Government of Pakistan (Chairani, 2018).

Although, the Pakistani government has implemented penalties and punished for handling the cases of honor killing in Pakistan by getting in the suspects into the prison. However, this punishment did not affect to suspects because the suspects could pay 'diyat' for monetary compensation, thus making the suspects not getting into prison and get the prison sentences relief (Asruchin M. , 2018).

\section{CONCLUSION}

The problem of gender inequality in Pakistan has been going on for years. This is proven by the results of a report from The Global Gender Gap Index in 2018 which was released by The World Economic Forum (WEF), Pakistan is the second worst country in the world in terms of gender equality, especially for women, which ranks 148 out of 149 countries. And in previous years, Pakistan also occupied the lowest position in terms of gender equality. This gender equality can be measured by 4 fundamental aspects, they are: participation and economic opportunities, educational attainment, health and survival and political empowerment. This means that Pakistan is still unable to handle the four fundamental aspects.

Therefore, by applying the concepts of feminism and human rights in this research, it is necessary Pakistan joining in CEDAW. Because women's participation and contribution in a country by guaranteeing the freedom their society. But its obstructed by patriarchal socioculture, which men must dominate in all aspects. Therefore, gender inequality still exists and honor killing cases still ineffective and is not handling yet in Pakistan.

Thus, if there is a lack of women's participation, this will be one of the 
roots of the economic and demographic problems that have been experienced by Pakistan until today. The reasons of gender inequality problems have been going on for a long time in Pakistan, due to various factors, they are:

First, lack of the role of the Government of Pakistan in prioritizing some sectors that can support Pakistan's economic progress by loosening its policies towards women.

Second, social norms that do not support women's involvement in economic activities, thus requiring them to return to the informal sector, their employment sector does not have skills in their work (Quresh, 2019). Fourth, the gender wage gap is still very high in the world, causing low participation and women's wages in socio- economic sector skills.

Therefore, Pakistan requires women's participation and contribution getting into the working world in the public and economic sectors. Besides that, a policy on gender equality is needed and there must be a transformation of social norms that can change the status of women's socio-economic participation in positioning their status in a country (Quresh, 2019).

There are some roles from the Pakistan's Government for solving the gender inequality problems, by ratifying the Convention on the Elimination of all Forms of Discrimination Against Women (CEDAW). But Pakistan still does not have a sense of responsibility to eliminate the problem of discrimination against women. Besides that, The Government of Pakistan also gives some penalties and punishment for suspects who have committed acts of gender discrimination. But the punishment and penalty are not yet effectively implemented. By forming a Commision of Inquiry for Women in 1997 which serves to provide policy recommendations in dealing with honor killing as a form of implementing CEDAW. However because of socio cultural, this policies are hard to implementing in every sector because its only proposing the analyze like honor killing and not yet to overcome the inequality gender in Pakistan.

\section{RECOMMENDATION}

First, Pakistan Government must have the right mechanism in implementing a policy that will ultimately monitor and control the constitutional rights and procedures of a country. Thus, the Pakistan Government must not be bored and tired, especially they must always pay attention to gender inequality. 
Second, the Constitution of Pakistan should be more able to protect the equal rights of women and men in the same work.

Third, globalization related policies must also begin to be implemented and enhanced for transformation in the socio-economic sector and employment and markets.

Fourth, must improve the quality and capabilities related to economic, political and social regulations on women, so that they can live their lives well and be equal to men.

Justice for Pakistani women requires a broader government effort, including more state prosecutions of 'honor killings', reformed criminal laws, and greater access for women and girls to safe emergency shelters and other services when they report risks from their family. The government should end a system in which a women's life is considered worthless and family members can kill with impunity (Ijaz, 2019).

\section{REFERENCE}

Agustina, R. (2014) Perempuan Pakistan Tetap Bekerja Meski Upab Minim. Sindo News (Online). Available at:

https://nasional.sindonews.com/berit a/935427/149/perempuan-pakistantetap-bekerja-meski-upah-minim (Accessed: 5 July 2020).

Ahmed, A. (2018) Pakistan Among Worst Performers on Gender Equality: WEF. DAWN News (Online). Available at: https://www.dawn.com/news/14522 84 (Accessed: 5 July 2020).

Asruchin, M. (2012) Honour Killing di Pakistan, Wanita Sebagai Lembaga Properti dan Lambang Kehormatan Pria. Kompasiana (Online). Available at: https://www.kompasiana.com/asruch in $/ 55125 \mathrm{c} 7 \mathrm{c} 8133119 \mathrm{e} 53 \mathrm{bc} 67 \mathrm{c} 0 /$ hono ur-killing-di-pakistan-wanita-sebagaiproperti-dan-lambang-kehormatanpria (Accessed: 5 July 2020).

Asruchin, M. (2018) Honour Killing di Pakistan. Kompasiana (Online). Available at: https://www.kompasiana.com/asruch in/5a54a25ecaf7db03530c85f2/hono ur-killing-di-pakistan?page $=$ all (Accessed: 6 July 2020).

Bhanbaro, Sadiq, Wassan, M. Rafique, Shah, Muhbat, Talpur, Ashfaq A, Aijaz Ali. (2013) Karo Kari: The Murder of Honour in Sindh Pakistan: An Ethnography Study (Online). Vol. 3, No. 7: 1467-1484, pp. 3-19. Available at: https://shura.shu.ac.uk/7287/1/KA RO_KARI_THE_MURDER_OF_HONOUR_I N_SINDH_PAKISTAN_AN_ETH NOGRAPHIC_STUDY.pdf (Accessed: 6 July 2020).

CEDAW. (1979) United Nations Human Rights Office of the High Commissioner: Convention on the Elimination of All Forms of Discrimination against $W$ omen. New York: United Nations. Annual Report.

CEDAW. (2005) Convention on the Elimination of All Forms of Discrimination Against Women: Consideration of reports submitted by States parties under article 18 of the Convention on the Elimination of All Forms of Discrimination against Women. United Nations. Annual Report.

Chairani, M. (2018) Hambatan dalam Implementasi CED $A W$ di Pakistan: Studi Kasus Honour Killing (Online) Vol. 7, No. 1, pp. 144-145. Available at: 
http:/ / repository.unair.ac.id/69558/3 /JURNAL_Fis.HI.02\%2018\%20Cha \%20h.pdf (Accessed: 6 July 2020).

Cochran, M. Q. (2007) A Guide To Using Qualitative Research Methodology. United Kingdom: Medecins Sans Frontieres (MSF) Publisher.

Direktorat, J. K. (2019) Memahami Metode Penelitian Kualitatif. Artikel DJKN. (Online). Available at: https://www.djkn.kemenkeu.go.id/ar tikel/baca/12773/MemahamiMetode-Penelitian-Kualitatif.html (Accessed: 7 July 2020).

Fondation, W. I. (2019) Gender Pay Gap Around the World 2019: Gender Pay Gap in Asia in \% - Ranked According to World Economic Forum - 2019 Data -Check Pakistan. Wage Indicator (Online). Available at: https://paycheck.pk/salary/genderpay-gap (Accessed: 7 July 2020).

Hancock, B. E. (2009) An Introduction to Qualitative Research (Online). Available at: https://www.rdsyh.nihr.ac.uk/wpcontent/uploads/2013/05/5_Introdu ction-to-qualitative-research-2009.pdf (Accessed: 6 July 2020).

Hisam, Z. (2016) Gender Wage Gap. DAWN News (Online). Available at: https://www.dawn.com/news/12606 29 (Accessed: 7 July 2020).

HRCP, H. R. (2004) Media Monitoring of Human Rights Violations and Concerns in Pakistan. HRCP: Human Rights Commission of Pakistan. Annual Report.

Ijaz, S. (2019) Pakistan Should Not Again Fail 'Honour Killing' Victim. Human Rights Watch News (Online). Available at: https://www.hrw.org/news/2019/08 $/ 22 /$ pakistan-should-not-again-failhonor-killing-victim (Accessed: 7 July 2020).

Jamal, H. (2015) The Origin of Honour Killing
(Karo-Kari) in Sindh Pakistan: A Discussion on Islamic Context (Online). Vol. 7, pp. 66-70. Available at: https://sujo.usindh.edu.pk/index.php /THE-

WOMEN/article/view/631/464 (Accessed: 6 July 2020).

Khan, A. (1999) Mobility of Women and Access to Health and Family Planning Services in Pakistan. pp. 39-48. Available at: https://www.tandfonline.com/doi/ab s/10.1016/S09688080\%2899\%2990005-8 (Accessed: 8 July 2020).

McCusker, S. G. (2015) Research Using Qualitative, Quantitative or Mixed Methods and Choice Based on the Research (Online). Available at: https://pubmed.ncbi.nlm.nih.gov/25 378417/ (Accessed: 8 July 2020).

Muliadi. (2009) Hak Asasi Manusia. Bandung: Refika Aditama.

Mursalin, F. U. (2017) Efektivitas Implementasi Convention on the Elimination of $A l l$ Forms of Discrimination Against Woman (CEDAW) Terbadap Penurunan Diskriminasi Perempuan di Pakistan. Skripsi Departemmen Ilmu Hubungan Internasional. Makasar: S1 FISIP/ Hubungan Internasional. Universitas Hasanuddin.

Nations, U. (1979) Convention on the Elimination of All Forms of Discrimination against Women New York: United Nations Human Rights Office of the High Commissioner 18 December 1979" (Online). Available at: https://www.ohchr.org/en/professio nalinterest/pages/cedaw.aspx (Accessed: 8 July 2020).

Pratiwi, R. D. (2012) Kajian Teori Gender. Skripsi. Yogyakarta: S1 Universitas Negeri Yogyakarta.

Quresh, U. (2019) Pakistan Has Highest Gender W age Gap in World. DAWN News (Online). Available at: https://www.dawn.com/news/14711 
48 (Accessed: 9 July 2020).

Reuters. (2017) Women Must Wait 217 Years to Earn the Same as Men, Index Says. DAWN News (Online). Available at: https://www.dawn.com/news/13680 23 (Accessed: 9 July 2020).

Human Right, U. N. (2008) What Are Human Rights. United Nations Human Rights. Annual Report.

Soetjipto, A. (2013) Gender Dalam Hubungan Internasional: Sebuah Pengantar.
Yogyakarta: Jalasutra.

Talpur, M. (2017) Women and Wages in Pakistan. Daily Times (Online).

Available at: https://dailytimes.com.pk/135254/w omen-wages-pakistan/ (Accessed: 9 July 2020). 